\title{
Slow and Deep Breathing Pranayamas Facilitate Recovery from COVID-19
}

\author{
Gopal Krushna Pal
}

\section{Gopal Krushna Pal}

Editor-in-Chief, IJCEP, INDIA.

\author{
*Correspondence \\ Dr. Gopal Krushna Pal \\ Editor-in-Chief, IJCEP, INDIA. \\ Phone: +91-93442 91160 \\ Email: drgkpal@gmail.com \\ History \\ - Submission Date: 05-05-2021; \\ - Review completed: 10-06-2021; \\ - Accepted Date: 18-06-2021.
}

DOI : 10.5530/ijcep.2021.8.2.12

Article Available online

http://www.ijcep.org

\section{Copyright}

(c) 2021 Phcog.Net. This is an openaccess article distributed under the terms of the Creative Commons Attribution 4.0 International license.
Though 80\% of Corona Virus Disease 2019 (COVID -19) patients recover without much medical intervention, the morbidities and mortality in the in the second wave of COVID-19 have been reported to be more. Though COVID-19 mortality is mostly due to acute pneumonia and acute respiratory distress syndrome (ARDS), it has also been reported that cardiac problems and cardiovascular (CV) risks are not less in this disease. ${ }^{[1]}$ Even after recovery, patients are dying due to cardio-respiratory complications in the post-recovery period. To date, there is no evidence of any effective treatment for COVID-19. In India alone at the peak of second wave, daily new cases reported were more than 4 lakhs and daily deaths were about 4000. Practice of yoga is known to improve cardiac and pulmonary functions. ${ }^{[2]}$ Among yoga techniques, pranayamas (controlled breathings) are more effective in promoting cardio-respiratory functions. ${ }^{[3]}$ Among different types of pranayamas, the chandranadi pranayama (left-nostril breathing) and anulom-vilom pranayama (alternate-nostril breathing) have been demonstrated to have maximum beneficial effects on autonomic and cardiopulmonary functions, especially if they are practiced in a single session of pranayama schedule. ${ }^{[4,5]}$ Recently, a slow and deep pranayama schedule integrating both these pranayamas has been reported to facilitate early recovery from COVID-19. ${ }^{[6]}$

Pranayama is the controlled breathing in which the practitioner regulates his breathing through structured and meticulous inhalation and exhalation. In normal breathing, the act of inspiration and expiration is often without conscious knowledge and the duration of inspiration is longer than expiration. Normally, the duration of expiration is less than half of the duration of inspiration. During inspiration, heart rate is more due to less vagal tone and during expiration heart rate is less due to more vagal tone. This phenomenon of alteration of heart rhythm tuned with inspiration and expiration is known as sinus arrhythmia. Knowing the benefit of this physiological phenomenon of sinus arrhythmia, ancient yoga practitioners had experienced pranayama as part of their natural living, in which expiration is prolonged much more than inspiration that strengthens vagal tone and improves sympathovagal homeostasis, and by practicing these pranayamas they lived healthily for centuries.
Pranayama is classified into two categories: fast pranayamas and slow pranayamas. ${ }^{[3]}$ In fast pranayamas such as kapalabhati, bhastrika, and bellows breathing, the respirations are quicker but deep. Usually, fast pranayamas increase sympathetic activity. Sympathetic tone also increases by practice of suryanadi pranayama (right nostril breathing).

The slow types of pranayamas are anulom-vilom (alternate nostril breathing), chandranadi (left nostril breathing), sitkari and sheetali (cooling breaths), and bhramari (breathing with vibrations through ear like a humming bee). In slow pranayama, respirations are slower, deeper, and more prolonged with greater duration of expiration. By reducing inspiration and lengthening expiration, the vagal nerve traffic is more strengthened.

i). In slow pranayamas, the duration of expiration is gradually increased by the practitioner in the proportion of (inspiration-expiration ratio) $1 ; 1,1: 2,1: 3$ or $1: 4$. With gradual increase in expiration, the duration of vagal activation becomes gradually more as per the process of sinus arrythmia. This improves vagal discharge and increases vagal tone. Thus, the heart rate is reduced, and the heart rate variability (HRV) is improved.

ii). It has also been explained that in slow pranayamas, gradual and graded increase in lung volume and rib cage increases nerve traffic from thoracic cage proprioceptors that strengthen vagal tone through the central limbic-hypothalamic influence of the sensory projections to thalamus and cortex.

iii). Furthermore, it has been observed that slow pranayamas augment cerebral blood flow and oxygenation that improves neuronal activities of the brain centers including those present in the limbic areas, hypothalamus, and medulla, the centers of autonomic discharge. This improves sympathovagal outflow by facilitating vagal discharge.

Thus, slow pranayamic breathings improve sympathovagal balance. ${ }^{[7]}$ Especially, practice of chandranadi pranayama (left-nostril breathing) and anuloma-viloma pranayama (alternate nostril breathing) is very effective in increasing vagal tone and decreasing sympathetic tone. By improving sympathovagal balance they improve visceral 
functions, increase insulin secretion and sensitivity, improve thyroid secretion and control metabolism, improve genito-urinary functions and reproductive functions. It has been recently reported that improvement in vagal tone is not only essential for stable cardiovascular (CV) health but also for maintaining fitness of the body as a whole, the integral health of the being. ${ }^{[8]}$

- Pranayama is directly linked to autonomic activity, regulation of heart rate, and heart rate variability (HRV). Decrease in heart rate physiologically by practice of yoga or exercise improves HRV.

- Although resting heart rate varies widely in general population between 60 to 100 beats/min, persistent tachycardia has been reported to decrease HRV, which is an established CV risk. It has been recently reported that heart rate more than $75 /$ min increases $\mathrm{CV}$ risk. As slow pranayamas are very effective in reducing heart rate and blood pressure, they profoundly decrease CV risks.

- In general, pranayamas improve CV health, in addition to overall holistic improvement of the health of the individual.

Pranayama being a deep breathing exercise, increases chest expansion, functioning of the respiratory apparatus, gas exchange across the alveolocapillary membrane and oxygenation of the tissues. ${ }^{[3]}$ By increasing oxygenation to brain, it increases neuronal functions in the brain and the functioning of the brain centers. Also, it increases learning, memory, cognition and higher intellectual functions. Thus, the improvement of working of cardiovascular and respiratory centers in the medulla by practice of pranayama help facilitate the better regulation of cardiopulmonary function. The major problems in COVID-19 patients are the decrease in $\mathrm{SpO}_{2}$ due to decreased ventilation and decreased oxygen transfer to the blood from lungs to interstitial pneumonia. ${ }^{[3]}$ If slow and deep breathing exercises such as pranayamas can be practiced from the beginning of the COVID-19 illness, the potency of respiratory apparatus will be maintained and the intensity of pneumonitis will be reduced. This will not only facilitate the early recovery from COVID-19, but also will prevent the post-recovery COVID-19 complications.

\section{REFERENCES}

1. Li LQ, Huang T, Wang YQ, Wang ZP, Liang Y, Huang TB, Zhang HY, Sun W, Wang Y. COVID-19 patients' clinical characteristics, discharge rate, and fatality rate of meta-analysis. J Med Virol. 2020;92(6):577-83. doi: 10.1002/jmv.25757, PMID 32162702.

2. Saraswati SS. Asanas. In: Asana pranayama mudra bandha. 4th ed. Munger, Bihar: Yoga publication trust; 2002. p. 2-11.

3. Pal GK, Pal P, Nanda N. Physiology of yoga and prevention of aging. In: Comprehensive textbook of medical physiology. 2nd ed. New Delhi, India: Jaypee Publications; 2019. p. 1359-76.

4. Joice PPS. Influence of Nadi Shodhana Pranayama on respiratory functions of postmenopausal women. Natl J Physiol Pharm Pharmacol. 2021;11(01):34-6.

5. Ankad RB, Herur A, Patil S, Shashikala GV, Chinagudi S. Effect of short-term pranayama and meditation on cardiovascular functions in healthy individuals. Heart Views. 2011;12(2):58-62. doi: 10.4103/1995-705X.86016, PMID 22121462.

6. Pal GK, Nanda N, Renugasundari M, Pal P. Prone Asanas and Pal's Pranayama could Facilitate Recovery and Prevent Psychosomatic Stress and Complications of COVID-19. Yoga Phys Ther Rehabil. 2020;5:1078. doi: 10.29011/25770756.001078 .

7. Pal GK, Velkumary S, Madanmohan. Effect of short-term practice of breathing exercises on autonomic functions in normal human volunteers. Indian $\mathrm{J}$ Med Res. 2004;120(2):115-21. PMID 15347862.

8. Pal GK. Effects of pranayama on cardiovascular health. Int J Clin Exp Physiol. 2016:3(2):57-8. doi: 10.4103/2348-8093.185201.

Cite this article: Pal GK. Slow and Deep Breathing Pranayama's Facilitate Recovery from COVID-19. Int J Clin Exp Physiol. 2021;8(2):47-8. 